\title{
PHYSICAL ACTIVITY OF WARSAW'S SIX YEAR OLD CHILDREN AND ITS CORRELATION WITH PHYSICAL FITNESS
}

\author{
DOROTA TRZCIŃSKA, PIOTR TABOR, ELŻBIETA OLSZEWSKA \\ The Jozef Pilsudski University of Physical Education in Warsaw, Faculty of Physical Education, \\ Department of Physical Education Theory and Correction
}

\begin{abstract}
Mailing address: Dorota Trzcińska, The Jozef Pilsudski University of Physical Education in Warsaw, Department of Physical Education Theory and Correction, 34 Marymoncka Street, 00-968 Warszawa, tel.: +48 602622 480, fax: +48 22 8651080, e-mail: dorota.trzcinska@awf.edu.pl
\end{abstract}

\begin{abstract}
Introduction. Physical activity and physical fitness are among the positive measures of health. Their assessment is justified from the point of view of prevention of many civilization diseases. The aim of this paper is to describe the physical activity of six year old children in Warsaw and to determine its relationship to physical fitness. Material and methods. The study was conducted in two series - in the spring of 2011 and 2012. Data were collected for 742 children from selected pre-school institutions in Warsaw. The average age of the children born in 2005 (2011 edition) and 2006 (2012 edition) was $5.84 \pm 0.31$ years. The numbers in both categories were equal, and amounted to 371 girls and boys. The choice of educational institutions was such, as to ensure that the sample was representative. In order to assess the children's physical activity, the method of diagnostic survey was used (questionnaire). The questionnaire addressed to the parents included questions about the participation of their children in pre-school, extracurricular and family forms of physical activity and the amount of time spent on passive leisure activities. To evaluate the physical fitness we used a test consisting of five motor trials (bend while sitting down, sit up from the lying position $30 \mathrm{~s}$, long jump from stationary position, run 10x5 m, $1 \mathrm{~kg}$ medicine ball throw forward). Mathematical analysis of the material utilised selected methods of descriptive statistics (including cluster analysis), standardization of data and the $\boldsymbol{x}^{2}$ test. Results. In the both gender subgroups three clusters were formed, corresponding to the above-average, average, and reduced physical fitness. Parents of children with the highest level of motor skills often declared significant participation of their children in family and extracurricular forms of physical activity and less time spent in front of TV or computer. Conclusions. In the population of six year old children in Warsaw positive relationship were found between the claimed physical activity and physical fitness.
\end{abstract}

Key words: physical activity, physical fitness, six year old children

\section{Introduction}

Physical activity and fitness are considered to be good indicators of health, and their nature and importance are emphasised in a number of publications [1, 2, 3]. J. Nowocień [2] - referring to previous sources - indicates five areas covering the entire period of ontogenesis, affected by physical activity. The first of them is associated with high quality and healthy lifestyle. The second one relates to the prevention of many diseases, especially of the socalled civilization diseases, mainly including overweight and obesity, type II diabetes and cardiovascular diseases. The third one - therapeutic treats physical activity as a therapeutic or a correction agent to a variety of developmental disorders. Physical activity also plays an important role in reducing increased nervous tension resulting from stress (fourth area). Finally, the fifth one of these areas is referred to as positive aging.

Physical fitness is highly dependent on physical activity. Together with rational nutrition, it determines the state of health at all stages of life. Appropriate level of physical activity affects physical development, motor and psychosocial development of children and adolescents [4]. In the literature we can find a number of arguments in support of the beneficial effect of an active lifestyle of the level of physical fitness. This applies program of activities undertaken during physical activities at educational institutions, as well as other forms of, extracurric- ular, so called out of school (extracurricular organised) and family activities $[5,6,7,8,9,10,11]$. Unfortunately, reports on the current state of both physical activity and physical fitness of children and adolescents are highly disturbing [4, 12, 13]. Observation of changes in physical activity of Polish youth from the late 90s shows that its level decreases with age and is consistently lower than recommended. According to the HBSC report (Health Behaviour in School-aged Children) of 2010, "one of the causes of low physical activity of children and adolescents is the development of new information and communication technologies, including those utilising cell phones, computers and the Internet. The use of these technologies results in immobilization of the user for many hours, and because of its attractiveness compete with mobility classes" [4]. The HBSC international project is being implemented in a total of 43 countries in Europe and North America. In Poland, these studies were carried out three times in the 90s, and then in 2002, 2006 and 2010. In its latest edition, based on survey data obtained from a survey of young people 11-18 years, levels of physical activity in this age group were assessed. It turned out that the recommended standards (at least one hour of moderate or high activity per day) were not satisfied by the vast majority of students (a total of more than $80 \%$ ). This percentage is better in the younger than in the older age categories (about $73 \%$ in $5^{\text {th }}$ grades of primary school and nearly $90 \%$ of high school students), and among boys compared with girls [4]. A negative opinion on the 
state of youth's physical activity was formulated by Kościelnik and Jopkiewicz [13] on the basis of an over 1500 strong group of school children aged 11-16 from Mazowieckie and Swiętokrzyskie voivodeship. It was demonstrated that only $30 \%$ of patients achieved satisfactory, almost $45 \%$ - low, and about $25 \%-$ a very low level of physical activity. Similar results were presented in the work of Marchewka et al. [14], on the health behaviours of secondary school students in Bielsko-Biala. The authors stated in the conclusion that only a small proportion of the young people undertake physical activity recommended by the experts, despite its knowledge of the health and aesthetic values.

The assessment of physical fitness of children and youth in Poland is facilitated cross-section surveys of student population repeated every 10 years, conducted since 1979 by the Department of Physical Education Theory of the Jozef Pilsudski University of Physical Education in Warsaw. Its last edition covering over 50000 girls and boys aged 7-19 years were conducted in 2009 and 2010. In the light of the mentioned studies, in the physical fitness tests, including Eurofit - international test and a 12 minute Cooper run, over the 1999-2009/ 2010 decade a significant deterioration in performance in terms of both men and women and the vast majority of age groups was found. The decline in motor skills applied to all motor abilities coordination, strength in endurance and speed events. In the tests: long jump from stationary position, $50 \mathrm{~m}$ run and $4 \times 10 \mathrm{~m}$, sit up from lying position, regression of the results obtained was remonstrated especially in the younger age categories (710 years) [12].

In the context of the evidence presented in the literature, what seemed interesting was the diagnosis of physical activity and fitness in the final stage of pre-school education - important from the point of view of development of healthy habits. Therefore, the aim of the study was to characterise the physical activity of six year old children in Warsaw and to determine its relationship to physical fitness.

\section{Material and methods}

The study was conducted in two series - in the spring of 2011 and 2012. The data were collected for 742 children in selected kindergartens in Warsaw. The average age of children born in 2005 (2011 edition) and 2006 (2012 edition) was $5.84 \pm 0.31$ years. The numbers in both categories were equal, and amounted to 371 girls and boys. The choice of educational institutions was such, as to ensure that the sample was representative.

In order to assess the children's physical activity, the method of diagnostic survey was used (questionnaire).

The questionnaire addressed to the parents included questions concerning their children's lifestyles, grouped into 4 groups:

- Do you/how often/ engage into family physical activities (e.g. walking trips, bicycle rides, swimming pool visits, ski outings etc.)?

- Does your child participate in extracurricular activities in the kindergarten (if so, how many)?

- Does your child participate in extracurricular activities organised by other institution than the kindergarten (if so, how many)?

- Generally, how much time does your child spend watching TV or playing computer games?

Based on answers provided by the respondents, data were obtained on participation of the respondents in pre-school and family and extracurricular organised physical activities and the timing of passive leisure activities. The survey questions were of multiple choice nature, with one answer to be selected (so- called disjunctive cafeteria) or semi-open ended.

To evaluate the physical fitness we used a test consisting of five motor trials (bend while sitting down, sit up from the lying position $30 \mathrm{~s}$, long jump from stationary position, run $10 \times 5 \mathrm{~m}, 1 \mathrm{~kg}$ medicine ball throw forward).

Mathematical analysis of the material utilised selected methods of descriptive statistics (including cluster analysis), standardization of data and the $\boldsymbol{X}^{2}$ test. For standardized numerical values specifying the level of physical fitness of children, a cluster analysis was performed. This method was used for the isolation of homogeneous subsets of the population selected in such a manner as to ensure that object qualified for a number of groups (three - in the case of this study) were as similar to each other as possible, and at the same time that the groups were as different from each other as possible (15). In cluster, we examined the prevalence of individual responses to survey questions about the child's level of physical activity in the family. The significance of differences between the abovementioned frequencies was verified using the $\boldsymbol{X}^{2}$ test, assuming statistical significance levels of ** $\mathrm{p}<0.01$ and ${ }^{*} \mathrm{p}<0.05$.

\section{Results}

Presentation of the research results was divided into two parts. The first one of them relates to the characteristics of physical activity of six year old children in Warsaw, the second one attempts to determine the relationship between their activity and physical fitness. Figures 1-4 show the percentage distribution of response quoted in "Materials and Methods" survey questions.

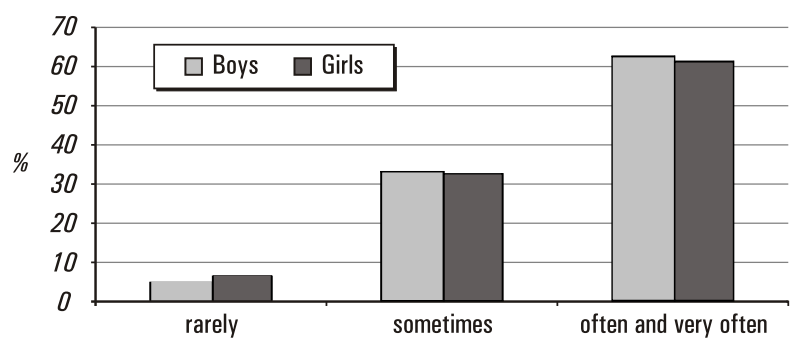

Figure 1. Percentage distributions of responses to survey questions regarding undertaking family physical activity in the tested group

In the responses to the survey question about the frequency of physical activity undertaken in the family, the most frequently selected options included "often and very often", corresponding to at least twice a week, or even daily activities undertaken by parents and children. This option was selected by over $60 \%$ of the respondents, parents of both boys and girls. The answer "sometimes" (once a week) was selected by another $30 \%$ of the respondents. The "rarely" option was selected least often (4.7\% - boys, $6.5 \%$ - girls) (Fig. 1).

The respondents reported widespread participation of their children in physical activities in the kindergarten. Among those, the most frequently mentioned forms of physical activity included fitness and dancing exercises (eurhythmics), corrective gymnastics and dance classes. According to the parents, nearly $70 \%$ of boys and $76 \%$ girls participated in three or more additional physical activities. The second most common answer choice (almost 19\% of parents of boys and more than 15\% of parents of girls) was participation in two extracurricular activities. The option of 1 activity was reported rarely $(8.5 \%$ boys and $6 \%$ - girls), and the option "not involved" was selected only marginally (respectively 3.3\% and 2.7\%) (Fig. 2). 


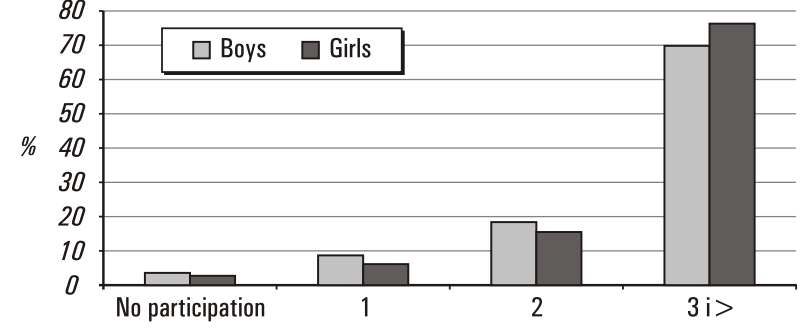

Figure 2. Percentage distributions of responses to survey questions regarding the participation of tested children in pre-school physical activities

In the responses to the survey question about the child involvement in organised extracurricular physical activities the most often selected option was "not involved". This option was selected by around $50 \%$ of the respondents, while a further $30 \%$ of parents reported the child participation in some one form of such activities (more boys than girls). The option "two forms of activity" was selected about around 10\% of times, and only a few respondents acknowledged the child engaging in three or more extracurricular forms of physical activity (more than $3 \%$-boys and about $2 \%$ - girls) (Fig. 3 ).

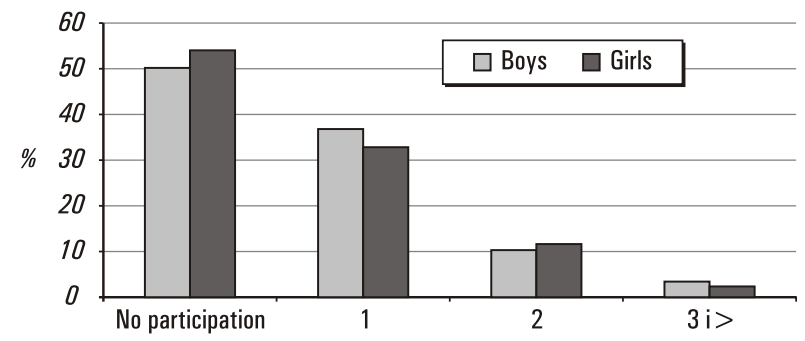

Figure 3. Percentage distributions of responses to survey questions regarding the participation of tested children in extracurricular physical activities

The most frequently declared response to the question about the time spent by the child in front of TV or computer "1-2 hours a day" (about 45\%). Slightly fewer (40\%) were selected the option "less than 1 hour". Longer passive leisure time (2-3 hours) was indicated by more than $10 \%$ of parents of boys and less than $10 \%$ of parents of girls. The answer "more than three hours" was chosen least often (1.9\% and 1.4\%) (Fig. 4).

It should be noted that the frequency of selection of individual variants answers to the questions in the survey differed slightly among parents of boys and girls (Fig. 1-4).

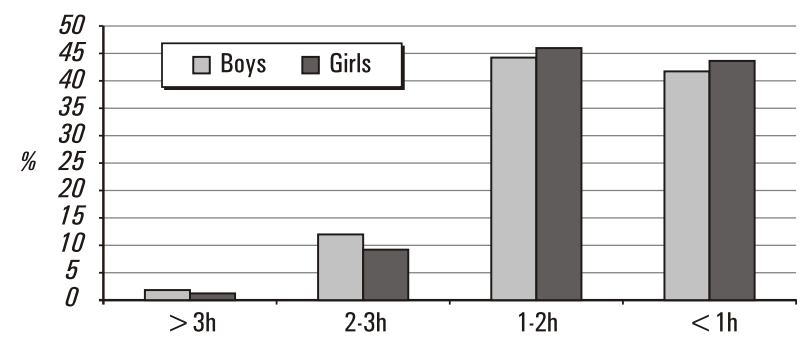

Figure 4. Percentage distributions of responses to survey questions regarding the amount of time spent on passive leisure activities
Analysing the physical fitness test, in the both gender subgroup, 3 clusters were found to exist, corresponding (roughly speaking) the above-average (line with diamonds), average (line with squares) and the reduced (line with triangles) level. The regular pattern of the results was consistent with highlighted notes of motor skills levels in the jumping, running and ball throwing tests. In the case of abdominal muscle strength test (sit ups from lying position) the III cluster respondents obtained better results than the II cluster children. However, in the test bend forward in sitting down position best results were obtained by the II cluster boys, and the poorest results were obtained by the III cluster boys. Among the girl, in the same test, the results were as follows: cluster I, III, II. In all performance tests of physical fitness, in the both gender categories, cluster I respondents performed better than the cluster III subgroup. The biggest differences between the extreme clusters were observed among boys in the jumping test (SD 1.5) and in the case of girls in jumping and running tests (more than 1.5 SD) (Fig. 5).

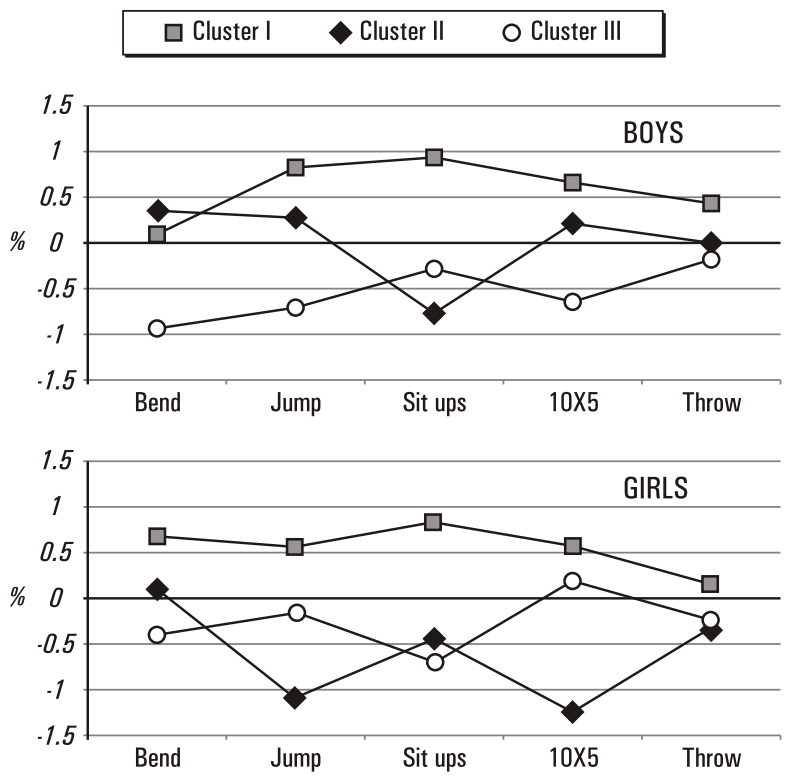

Figure 5. The standardized values of the tests of physical fitness in isolated groups of tested boys and girls

After the selection of clusters, frequency of answering survey questions about the level of physical activity was determined (including the belonging of the respondents to one of the clusters). Analysis of the figures contained in Table 1 shows differences in the level of physical activity of respondents, qualified to various physical fitness groups. This applies to both gender categories. A significant relationship was discovered between children's fitness and their participation in organized extracurricular physical activities. This relationship was found in both, the boys subgroup ( $p<0.01$ ) the girls subgroup ( $p<0.05$ ). Differences in the children's participation in this form of activity were observed between I and II cluster respondents. Trends of a similar nature were noted in the case of family physical activity (girls $-\mathrm{p}<0.01$ ) and passive leisure activities (boys $\mathrm{p}<0.05$ ). These differences were again related to respondents from extreme clusters (I-III). 
Table 1. Percentage distributions of responses to survey questions regarding the level of physical activity (including allocation of the subjects to one of the clusters)

\begin{tabular}{|c|c|c|c|c|c|c|}
\hline \multirow{2}{*}{ Response } & \multicolumn{3}{|c|}{ Cluster } & \multicolumn{3}{|c|}{ Cluster } \\
\hline & I & II & III & I & II & III \\
\hline & \multicolumn{3}{|c|}{ Boys } & \multicolumn{3}{|c|}{ Girls } \\
\hline \multicolumn{7}{|c|}{ Family physical activity } \\
\hline not at all, rarely & 2 & 4 & 10 & $6^{* *}$ & 4 & 10 \\
\hline sometimes & 30 & 35 & 34 & $24 * *$ & 36 & 38 \\
\hline often, very often & 68 & 61 & 56 & $71^{* *}$ & 60 & 52 \\
\hline \multicolumn{7}{|c|}{ Kindergarten organised physical activities (classes) } \\
\hline no participation & 2 & 5 & 3 & 4 & 1 & 3 \\
\hline one class & 11 & 5 & 9 & 9 & 3 & 5 \\
\hline two classes & 16 & 19 & 23 & 17 & 13 & 15 \\
\hline$>$ three classes & 71 & 71 & 65 & 70 & 83 & 76 \\
\hline \multicolumn{7}{|c|}{ Extracurricular physical activities } \\
\hline no participation & $46^{* *}$ & 52 & 54 & $46^{*}$ & 55 & 60 \\
\hline one class & $34^{* *}$ & 38 & 40 & $34^{*}$ & 31 & 33 \\
\hline two classes & $13^{* *}$ & 8 & 3 & $16^{*}$ & 12 & 7 \\
\hline$>$ three classes & $4^{* *}$ & 2 & 2 & $4^{*}$ & 1 & 1 \\
\hline \multicolumn{7}{|c|}{ Passive forms of leisure (television, computer etc.) } \\
\hline over $3 \mathrm{~h}$ & $1^{*}$ & 2 & 3 & 1 & 3 & 1 \\
\hline $2-3 \mathrm{~h}$ & $9 *$ & 10 & 20 & 7 & 6 & 14 \\
\hline $1-2 \mathrm{~h}$ & $50^{*}$ & 47 & 33 & 44 & 48 & 46 \\
\hline$<1 \mathrm{~h}$ & $40^{*}$ & 41 & 45 & 48 & 44 & 39 \\
\hline
\end{tabular}

* - different from cluster III, $\mathrm{p}<0,05$; * * different from cluster III, $\mathrm{p}<0,01$

\section{Discussion}

The results of the studies demonstrate positive effects of physical activity of six year old children in Warsaw, and confirm the positive relationship between the declared activity and physical fitness.

The percentage distributions demonstrate frequent involvement of the tested boys and girls in the family forms of active leisure (Fig. 1) and their participation in pre-school physical activities (Fig. 2). As far as the tested group was concerned, organised forms of extracurricular activities proved to be less popular. The referenced research also provided some optimistic data on passive forms of leisure activities.

Despite some inconsistency in the research methods and techniques (making it difficult to directly compare the two groups) it can be considered the study achieved significantly better results on the level of physical activity than in the diagnosis of 11-18 year old adolescents [4]. Also, the study performed by Czaprowski et al. [16] on sedentary behaviour of children and adolescents aged 7-16 years shows that younger students in static positions spend less time than girls and boys in junior high school and older elementary school children. These authors documented that with age there is a significant increase in such behaviour, both, on, daily and weekly basis. Analysis of physical activity of a select group of primary and secondary schools children has shown that 7 year olds (i.e. close to the age group covered by this study) compared to older children, spent less time walking to school and back road walking to and from school or participating in extracurricular physical activities [17].

Some of the research results concerning the relationship between activity and physical fitness are repeatedly confirmed the importance of physical activity for the development of children documented in literature. Let us recall that in the present study has demonstrated higher level of motor skills in Warsaw's 6-year-olds combined with claimed frequent participation in organized extracurricular forms of active leisure. Similar results were obtained in studies of selected groups of children and adolescents $[7,8,10,18]$.

Positive changes in physical fitness (and somatic built) due to increased physical activity were reported in the studies of a selected group of 14-15 year old girls and boys [7]. The annual observation demonstrated improved physical fitness of youths (mostly girls) participating in extracurricular physical activities as compared to their peers involved only compulsory school physical education classes. This was the case in long jump from stationary position, with space $4 \times 10$ m shuttle run and sit ups from lying position. Significantly better results in the same performance tests were reported in studies of over 900 strong group of young people of Kielce aged 10-15 years with different levels of physical activity [18].

Impact of recreational forms of physical activity on changes in exercise capacity and physical fitness has been shown in the research studies of 10-12 year old boys published by Poliszczuk et al. [8]. The researchers utilised Denisiuk's tests of strength, power, speed, agility and endurance, measures heart rate and performed the Ruffier test. The study demonstrated that "each motor skill in people recreationally involved in sport was developed at a higher level than in the control group". At the same time it was found that "adaptive changes in physiological parameters in the tested boys were clearly visible in the heart rate". In addition, it was noted that "physical activity differentiated the tested children in terms of cardiovascular fitness" [8].

Similar trends were observed in the study of a 44 strong group of 15-16 year old boys from Warsaw, practicing volleyball. Compared to their tall peers the young volleyball players demonstrated significantly higher levels of fitness in most parts of the test sample of the international test (except pull ups). Particular advantage of the boys involved in volleyball achieved significantly better results in the jumping ability test.

\section{Conclusions}

Based on the presented test results set against data referenced in the literature the following conclusions have been drawn:

1. Physical activity of six year old children in Warsaw can be assessed positively. It is mainly based on family forms of active recreation and physical activities organized in the kindergarten. It seems that at this stage of life sedentary behaviour does not pose a threat to orderly development processes.

2 . The study confirmed the existence of a relationship between activity and physical fitness. Parents of children with higher motor skills declared their frequent participation in family, kindergarten, and especially extracurricular physical activities and little time spent on passive leisure.

\section{Acknowledgements}

The research was accomplished within the framework of statutory research project of the Josef Pilsudski University of Physical Education in Warsaw - DS. 139 - financed by the Ministry of Science and Higher Education. 


\section{Literature}

1. Bonikowska-Zgaińska M. (2011). The role of physical activity in developing and retaining a person's mental and physical fitness. In R. Asienkiewicz (Ed.), Humanistic and social issues of physical education (pp. 9-19). Zielona Góra: Uniwersytet Zielonogórski.

2. Nowocień J. (2013). A study on physical education pedagogy. Studia i Monografie nr 142. Warszawa: AWF. [in Polish]

3. Starosta W. (2011). The importance of a minimum of physical activity of man to his health and quality of life. In J. Tatarczuk, R. Sienkiewicz, E. Skorupka (Eds.), Ontogeny and health promotion in the context of medicine, anthropology and physical education (pp. 253-264). Zielona Góra: Uniwersytet Zielonogórski. [in Polish]

4. Mazur J., Małkowska-Szkutnik A. (Ed.) (2011). HBSC results, A technical report. Warszawa: IMiDz. [in Polish]

5. Dąbrowski A. (1997). Extracurricular physical education of young people - the reality, the needs and the expectations. Studia i Monografie. Warszawa: AWF. [in Polish]

6. Kalecińska J. (2007). Sporting families as an environment for recreational physical activity. Praca doktorska, Akademia Wychowania Fizycznego, Warszawa. [in Polish]

7. Pastuszak A., Małolepsza A., Kasznicki P. (2008). Effects of physical activity on body composition and physical fitness of young people. In A. Kuder, K. Perkowski, D. Śledziewski (Eds.), The improvement process in training and sport competition - diagnosis (pp.141-144). Warszawa: Polskie Towarzystwo Naukowe Kultury Fizycznej.

8. Poliszczuk D., Poliszczuk T., Leończuk K. (2009). The impact of recreational forms of physical activity on changes in exercise capacity and physical fitness in boys aged 10-12 years. In J. Nowocień (Ed.), Socio-Educational facets of contemporary sport and Olympism vol. I (pp.130-147). Warszawa: AWF. [in Polish]

9. Staniszewski T. (2007). Assumed and actual functions of schools in preparing children in early school age to physical recreation in the family. Studia i Monografie nr 1. Warszawa: AWF. [in Polish]

10. Trzcińska D., Tabor P., Olszewska E. (2009). The level of somatic development and physical fitness of male volleyball players aged 15-16. In K. Górniak, M. Lichota (Eds.), Correction and compensation of physical development disorders in children and youth (pp. 283-294). Biała Podlaska: ZWWF.

11. Umiastowska D. (2009). Physical fitness and participation in various forms of movement of children from primary schools in Zachodniopomorskie Voivodeship. In J. Nowocień (Ed.), Socio-Educational facets of contemporary sport and Olympism vol. I (pp. 148-158). Warszawa: AWF. [in Polish]
12. Dobosz J. (2012). Fitness and health of children and adolescents over the 30 years of political changes in Poland. Report of National debate on the conditions, the realities and challenges of physical education in Poland, November 28, 2012. Warszawa: AWF. [in Polish]

13. Jopkiewicz A., Kościelnik J. (2011). Physical activity and leisure activities of young people aged 11-16. In J. Tatarczuk, R. Asienkiewicz, E. Skorupka (Eds.), Ontogeny and health promotion in the context of medicine, anthropology and physical education (pp. 389-405). Zielona Góra: Uniwersytet Zielonogórski. [in Polish]

14. Marchewka J., Mucha A., Rogóż J., Kryst Ł. (2011). Physical activity during leisure time of students of secondary schools in Bielsko-Biala. In J. Tatarczuk, R. Asienkiewicz, E. Skorupka (Eds.), Ontogeny and health promotion in the context of medicine, anthropology and physical education (pp. 443456). Zielona Góra: Uniwersytet Zielonogórski. [in Polish]

15. Stanisz A. (2007). An accessible course of study in statistics using STATISTICA PL, based on medical examples. Multidimensional analysis vol.3. Kraków: StatSoft. [in Polish]

16. Czaprowski D., Biernat R., Stoliński Ł., Szczygieł A. (2011). Sedentary behaviour of children and adolescents in daily and weekly distribution. In J. Tatarczuk, R. Asienkiewicz, E. Skorupka (Eds.), Ontogeny and health promotion in the context of medicine, anthropology and physical education (pp. 343-363). Zielona Góra: Uniwersytet Zielonogórski. [in Polish]

17. Czaprowski D., Stoliński Ł., Szczygieł A., Kędra A. (2011). Extracurricular physical activity of children and adolescents in daily and weekly distribution. In J. Tatarczuk, R. Asienkiewicz, E. Skorupka (Eds.) Ontogeny and health promotion in the context of medicine, anthropology and physical education (pp. 325-342). Zielona Góra: Uniwersytet Zielonogórski. [in Polish]

18. Jopkiewicz A., Kochanowski J. (2011). Physical activity and fitness in children from two different social strata. In R. Asienkiewicz (Ed.), Humanistic and Social Issues of Physical Education (pp. 61-78). Zielona Góra: Uniwersytet Zielonogórski.

Submitted: February 28, 2013

Accepted: March 27, 2013 